\title{
Anisakidae and Raphidascarididae larvae parasitizing Selene setapinnis (Mitchill, 1815) in the State of Rio de Janeiro, Brazil
}

\author{
Larvas Anisakidae e Raphidascarididae parasitos de Selene setapinnis (Mitchill, 1815) no \\ Estado do Rio de Janeiro, Brasil
}

Gabrielle Fontenelle ${ }^{1}$; Marcelo Knoff ${ }^{*}$; Nilza Nunes Felizardo ${ }^{1}$; Eduardo José Lopes Torres ${ }^{3}$; Leila Maria da Silva Lopes $^{1}$; Delir Corrêa Gomes ${ }^{2}$; Sérgio Carmona de São Clemente ${ }^{1}$

\begin{abstract}
${ }^{1}$ Fishery Technology and Inspection Laboratory, School of Veterinary Medicine, Universidade Federal Fluminense - UFF, Niterói, RJ, Brazil

${ }^{2}$ Laboratory for Helminthic Parasites of Vertebrates, Instituto Oswaldo Cruz, Fundação Oswaldo Cruz - FIOCRUZ, Rio de Janeiro, RJ, Brazil

${ }^{3}$ Romero Lascasas Porto Helminthology Laboratory, Department of Microbiology, Immunology and Parasitology, School of Medical Sciences, Universidade Estadual do Rio de Janeiro - UERJ, Rio de Janeiro, RJ, Brazil
\end{abstract}

Received December 9, 2014

Accepted January 30, 2015

\begin{abstract}
Between February and August, 2012, thirty specimens of Atlantic moonfish, Selene setapinnis, were purchased in local markets in Niterói, State of Rio de Janeiro, Brazil, with the aim of analyzing the presence of anisakid nematodes, establishing their rates of parasitism and infection sites, due to importance in the sanitary inspection. A total of sixty nematode larvae, belonging to at least two species were found: nine larvae of Terranova sp., Anisakidae, with prevalence (P) of $13.3 \%$, mean intensity (MI) of 2.25 , mean abundance (MA) of 0.30 and range of infection intensity (RI) from 1 to 6; and 51 larvae of Hysterothylacium fortalezae, Raphidascarididae, with $\mathrm{P}=26.7 \%, \mathrm{MI}=6.40, \mathrm{MA}=1.70$, and $\mathrm{RI}=1-17$. The infection sites for Terranova sp. were the mesentery and liver serosa; and for $H$. fortalezae, the infection sites were the mesentery, abdominal cavity and liver serosa. New morphological data from scanning electron microscopy, on the external structures of $H$. fortalezae (mainly at the posterior end), are presented. This is the first report of $H$. fortalezae parasitizing $S$. setapinnis.
\end{abstract}

Keywords: Anisakidae, Raphidascarididae, Terranova sp., Hysterothylacium fortalezae, Selene setapinnis.

\section{Resumo}

De Fevereiro a Agosto de 2012, trinta espécimes de peixe galo, Selene setapinnis, foram adquiridos de mercados locais em Niterói, Estado do Rio de Janeiro, Brasil, com o objetivo de analisá-los quanto à presença de nematoides anisaquídeos, estabelecendo seus índices parasitários e sítios de infecção, devido a sua importância na inspeção sanitária. Do total de sessenta larvas de nematoides, pelo menos duas espécies foram encontradas: nove larvas de Terranova sp., Anisakidae, com prevalência (P) de 13,3\%, intensidade média (IM) de 2,25, abundância média (AM) de 0,30, e amplitude de variaçáo da intensidade de infecção (AI) de 1 a 6; e 51 larvas de Hysterothylacium fortalezae, Raphidascarididae, com $\mathrm{P}=26,7 \%, \mathrm{IM}=6,40, \mathrm{AM}=1,70$, e $\mathrm{AI}=1 \mathrm{a} 17$. Os sítios de infecção para Terranova sp. foram o mesentério e a serosa do fígado; e para $H$. fortalezae, os sítios de infecção foram o mesentério, cavidade abdominal e serosa do fígado. Novos dados morfológicos das estruturas externas, principalmente da extremidade posterior de $H$. fortalezae, são evidenciados por microscopia eletrônica de varredura. Este é o primeiro relato de $H$. fortalezae parasitando $S$. setapinnis.

Palavras-chave: Anisakidae, Raphidascarididae, Terranova sp., Hysterothylacium fortalezae, Selene setapinnis.

*Corresponding author: Marcelo Knoff, Laboratório de Helmintos

Parasitos de Vertebrados, Instituto Oswaldo Cruz, Fundaçâo Oswaldo Cruz

- FIOCRUZ, Avenida Brasil, 4365, Manguinhos, CEP 21045-900, Rio de

Janeiro, RJ, Brazil, e-mail: knoffm@ioc.fiocruz.br 


\section{Introduction}

Selene setapinnis (Mitchill, 1815), the Atlantic moonfish, reaches about $40 \mathrm{~cm}$ in length. It forms shoals and lives near the ocean bottom; however, individuals of small and medium size are very common in the shallow waters of bays and estuaries. These fish feed on other smaller fish and crustaceans. They are distributed from Nova Scotia, Canada, to the shores of the Gulf of Mexico and South America, reaching as far as northern Argentina (MENEZES \& FIGUEIREDO, 1980); they have commercial importance in Brazil, mainly in the southern and southeastern regions (BEGOSSI, 2011; CLAUZET et al., 2005; OCCHIALINI \& SCHWINGEL, 2003).

In Brazil, Cordeiro \& Luque (2004) analyzed the ecology of the community of parasitic metazoans of $S$. setapinnis along the coast of the State of Rio de Janeiro where the quantitative dominance of endoparasitic species was registered. In these localities, anisakid and raphidascaridid larvae showed high prevalence values, represented by Anisakis sp., Contracaecum sp., Terranova sp., Hysterothylacium sp. and Raphidascaris sp. According to these authors, this suggests that $S$. setapinnis occupies an intermediate trophic level in marine habitats, as part of the diet of piscivorous birds and marine mammals.

In addition to nematode larvae, digenetic trematodes have also been reported parasitizing $S$. setapinnis in Brazil: by Amato (1982) in the State of Santa Catarina and Wallet \& Kohn (1987) in the State of Rio de Janeiro. Dyer et al. (1985) also reported this in Puerto Rico.

The present study aimed to analyze the anisakid nematode larvae parasitizing S. setapinnis sold in markets in the municipality of Niterói, State of Rio de Janeiro, in order to establish their rates of parasitism, infection sites due to importance in the sanitary inspection.

\section{Materials and Methods}

Between February and August, 2012, thirty specimens of the fish species $S$. setapinnis (ranging in length from 37.0 to $46.0 \mathrm{~cm}$ and weight from 0.750 to $1.0 \mathrm{~kg}$ ) were purchased in the municipal market of Niterói, State of Rio de Janeiro, Brazil. They were transported in cool boxes to the Fishery Technology and Inspection Laboratory, School of Veterinary Medicine, Universidade Federal Fluminense, Niterói, State of Rio de Janeiro, for analysis on the presence of nematodes. The fish species was identified in accordance with Menezes \& Figueiredo (1980).

After the specimens had been necropsied and filleted, the nematode larvae that were found were placed in Petri dishes with
$0.65 \% \mathrm{NaCl}$ solution, fixed in hot AFA (alcohol, formalin and acetic acid) $\left(60{ }^{\circ} \mathrm{C}\right)$, preserved in a solution of $70{ }^{\circ} \mathrm{GL}$ ethanol plus 5\% glycerin and clarified with Amman's lactophenol, as described by Eiras et al. (2006).

The taxonomic classification of nematodes was made in accordance with Fagerholm (1991). The larvae were identified as described by Deardorff \& Overstreet (1981), Timi et al. (2001), Felizardo et al. (2009a) and Knoff et al. (2012).

Images from bright-field microscopy using Nomarski's differential interference contrast (DIC) were obtained using a Canon digital camera (Power Shot A640) coupled to a Zeiss Axiophot microscope. For topographic characterization of the cuticular surface, sixteen third-stage larvae of Hysterothylacium fortalezae Klein, 1973, were analyzed using SEM. This material was processed as described by Lopes Torres et al. (2013). The samples were examined under a JEOL 5320 scanning electron microscope operating at an acceleration voltage of $15 \mathrm{kV}$.

To clarify morphological details, drawings and analyses under SEM were produced only using $H$. fortalezae specimens. Morphometric analyses were done from drawings made on an Olympus BX41 microscope coupled to a drawing tube. Measurements are shown in millimeters $(\mathrm{mm})$ with the averages in parentheses, unless otherwise indicated. The parasitological indices of prevalence, mean intensity and mean abundance were obtained as described by Bush et al. (1997).

Representative specimens of Terranova sp. and $H$. fortalezae were deposited in the Helminthological Collection of the Oswaldo Cruz Institute (CHIOC), Rio de Janeiro, Brazil.

\section{Results}

Among the thirty specimens of S. setapinnis, ten (33.3\%) were infected by at least one species of nematode larvae. In total, sixty parasites were collected, belonging to the families Anisakidae and Raphidascarididae. Among the third-stage larvae $\left(\mathrm{L}_{3}\right)$ collected, nine were of Terranova sp. and 51 of $H$. fortalezae.

The parasitological indices of prevalence, mean intensity, mean abundance and range of infection, the infection sites and the CHIOC deposit number are shown in Table 1.

The morphometric and morphological data from the thirdstage larvae of Terranova sp. and $H$. fortalezae, obtained from four and ten specimens, respectively, are shown in Table 2 .

Anisakidae Railliet \& Henry, 1912

Terranova Leiper \& Atkinson, 1914

Terranova sp. (Figure 1)

Table 1. Prevalence (P), mean intensity (MI), mean abundance (MA), range of infection (RI), infection site (IS) and CHIOC deposit number of third-stage larvae collected from Selene setapinnis (January to August 2012) commercialized in the state of Rio de Janeiro, Brazil.

\begin{tabular}{ccccccc}
\hline & \multicolumn{5}{c}{ S. setapinnis } \\
\cline { 2 - 6 } & $\mathbf{P}(\%)$ & MI & MA & RI & IS & CHIOC \\
\hline Terranova sp. & 13.3 & 2.25 & 0.30 & $1-6$ & M, LS & 35851,35852 \\
H. fortalezae & 26.7 & 6.40 & 1.70 & $1-17$ & M, LS, AC & 35850 \\
\hline
\end{tabular}

$\mathrm{M}=$ mesentery; $\mathrm{LS}=$ liver serosa; $\mathrm{AC}=$ abdominal cavity. 
Description of the main morphological features observed in $\mathrm{L}_{3}$ : cuticle with crosscutting narrow striations most evident on the posterior body portion (Figure 1c); anterior end with a dorsal lip and two ventrolateral lips, all of them poorly developed (Figures 1a, 1b); a pair of cephalic papillae on the dorsal lip and a pair of cephalic papillae on each ventrolateral lip (Figure 1b); larval tooth below the mouth opening between the ventrolateral lips
(Figure 1b); excretory portion below the larval tooth (Figure 1b); ventricle longer than wide; absent ventricular appendix (Figure 1a); intestinal cecum larger than the ventricle (Figure 1a); three spherical rectal glands; and conical tail and absent mucron (Figure 1c).

Raphidascarididae Hartwich, 1974

Hysterothylacium fortalezae (Klein, 1973) (Figures 2, 3, 4)

Table 2. Morphological and morphometric data of Anisakidade and Raphidascarididae third-stage larvae collected from Selene setapinnis (January to August 2012) commercialized in the state of Rio de Janeiro, Brazil.

\begin{tabular}{lcc}
\hline & Terranova sp. & H. fortalezae \\
\hline Length & $3.75-6.12(4.81)$ & $4.50-7.0(6.05)$ \\
Width & $0.17-0.21(0.16)$ & $0.14-0.22(0.19)$ \\
Larval tooth & present & absent \\
Excretory pore* & opens beneath boring tooth & opens beneath nerve ring \\
Nerve ring** & $0.15-0.21(0.19)$ & $0.16-0.24(0.20)$ \\
Esophagus (L) & $0.52-0.81(0.67)$ & $0.57-0.80(0.70)$ \\
Ventriculus (L) & $0.25-0.43(0.33)$ & $0.055-0.060(0.058)$ \\
Ventriculus (W) & $0.13-0.16(0.14)$ & $0.055-0.065(0.060)$ \\
Ventricular appendix (L) & absent & $0.45-0.60(0.53)$ \\
Intestinal cecum (L) & $0.45-0.76(0.57)$ & $0.15-0.21(0.18)$ \\
Tail (L) & $0.12-0.28(0.17)$ & $0.12-0.20(0.17)$ \\
Mucron & absent & absent \\
Tuft of 6-8 spinous structures & absent & present \\
Spines (L) & - & $5.0-7.5(7.0) \mu \mathrm{m}$
\end{tabular}

${ }^{*}$ Inconspicuos in some specimens. ${ }^{* *}$ From anterior end; $\mathrm{L}=$ Length; $\mathrm{W}=$ Width. Measurements are in milimeters $(\mathrm{mm})$ with means in parentheses, unless otherwise indicated.
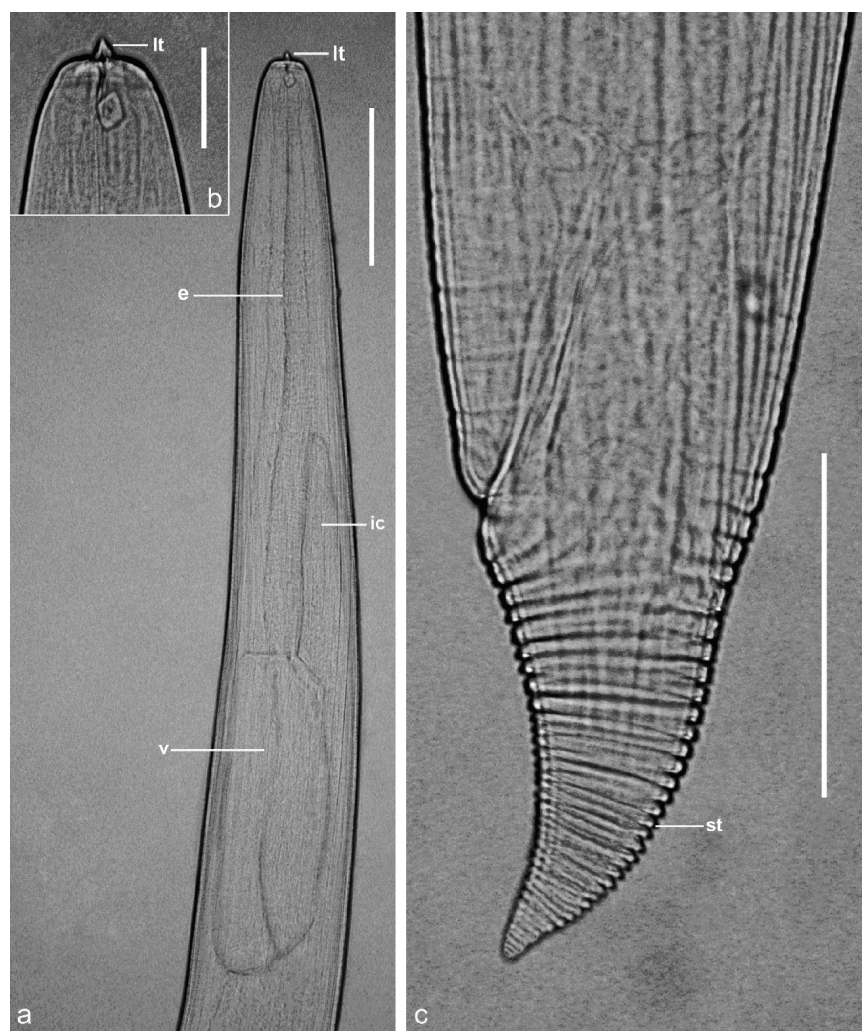

Figure 1. Terranova sp. $\left(\mathrm{L}_{3}\right)$ in Selene setapinnis: a - anterior portion showing larval tooth (lt), esophagus (e), ventricle (v) and intestinal cecum (ic); b - detail of larval tooth (lt); c - striated tail (st). Scale bars in $\mathbf{a}=200 \mu \mathrm{m}, \mathbf{b}=50 \mu \mathrm{m}$ and $\mathbf{c}=100 \mu \mathrm{m}$.
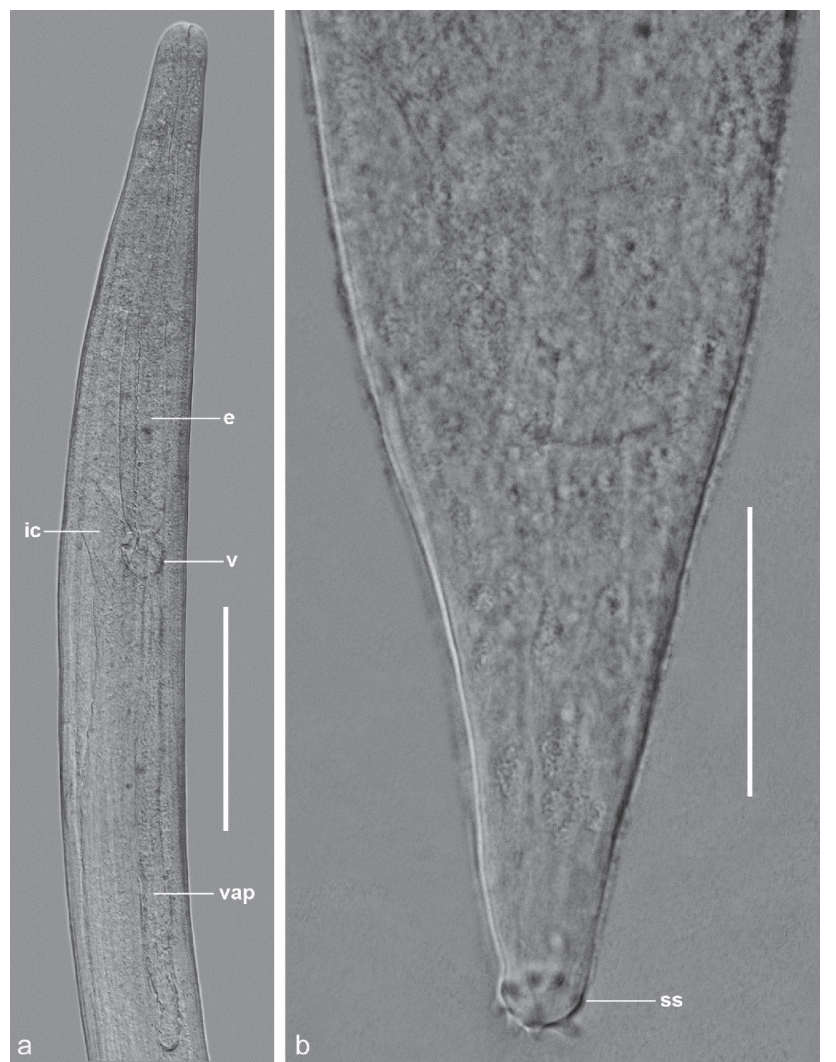

Figure 2. Hysterothylacium fortalezae $\left(\mathrm{L}_{3}\right)$ in Selene setapinnis: a - anterior portion showing esophagus (e), ventricle (v), ventricular appendix (vap) and intestinal cecum (ic); $\mathbf{b}$ - posterior portion with tuft of eight spinous structures (ss). Scale bars in $\mathbf{a}=200 \mu \mathrm{m}$ and $\mathbf{b}=50 \mu \mathrm{m}$. 


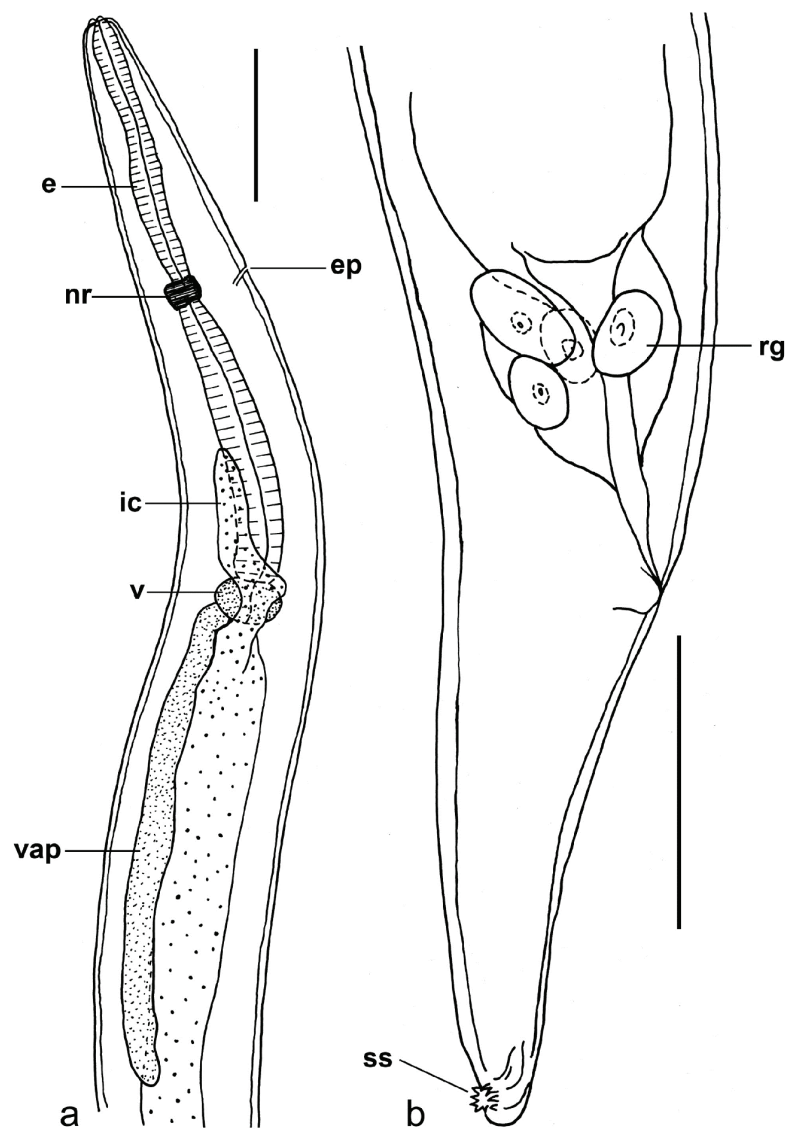

Figure 3. Hysterothylacium fortalezae $\left(\mathrm{L}_{3}\right)$ in Selene setapinnis: a - anterior portion showing esophagus (e), nerve ring (nr), excretory pore (ep), ventricle (v), ventricular appendix (vap) and intestinal cecum (ic); b - posterior portion with four rectal glands ( $\mathrm{rg}$ ) and tuft of eight spinous structures (ss). Scale bar in $\mathbf{a}=200 \mu \mathrm{m}$ and $\mathbf{b}=100 \mu \mathrm{m}$.

Description of the main morphological features observed in $\mathrm{L}_{3}$, under bright-field and SEM microscopy: triangular mouth provided with one dorsal lip, with two sets of papillae, and two lateroventral lips, each one with a set of papillae (Figures 2a, 4a); a smooth cuticular covering without evident cuticular transverse striations with a slightly prominent lateral line along the body, but not conspicuous at the anterior end (Figures 4b); excretory pore is adjacent to the nerve ring located in the first third of the esophagus (Figure 3a); ventricle is slightly spherical, esophagus is slightly larger than the ventricular appendix; intestinal cecum present (Figures 2a, 3a); four oval rectal glands, anus provided with a projection; conical tail curved ventrally provided with a tuft of six to eight spinous structures, but seven are commonly found (Figures 3b, 4b, c, d, e, f).

\section{Discussion and Conclusion}

Species of Terranova genus have been reported on the Brazilian coastal waters. Most of them were collected from teleost fish, and have been identified only as Terranova sp., with few or even none details of morphological and morphometric features about them, avoiding an accurate specific identification and comparison with
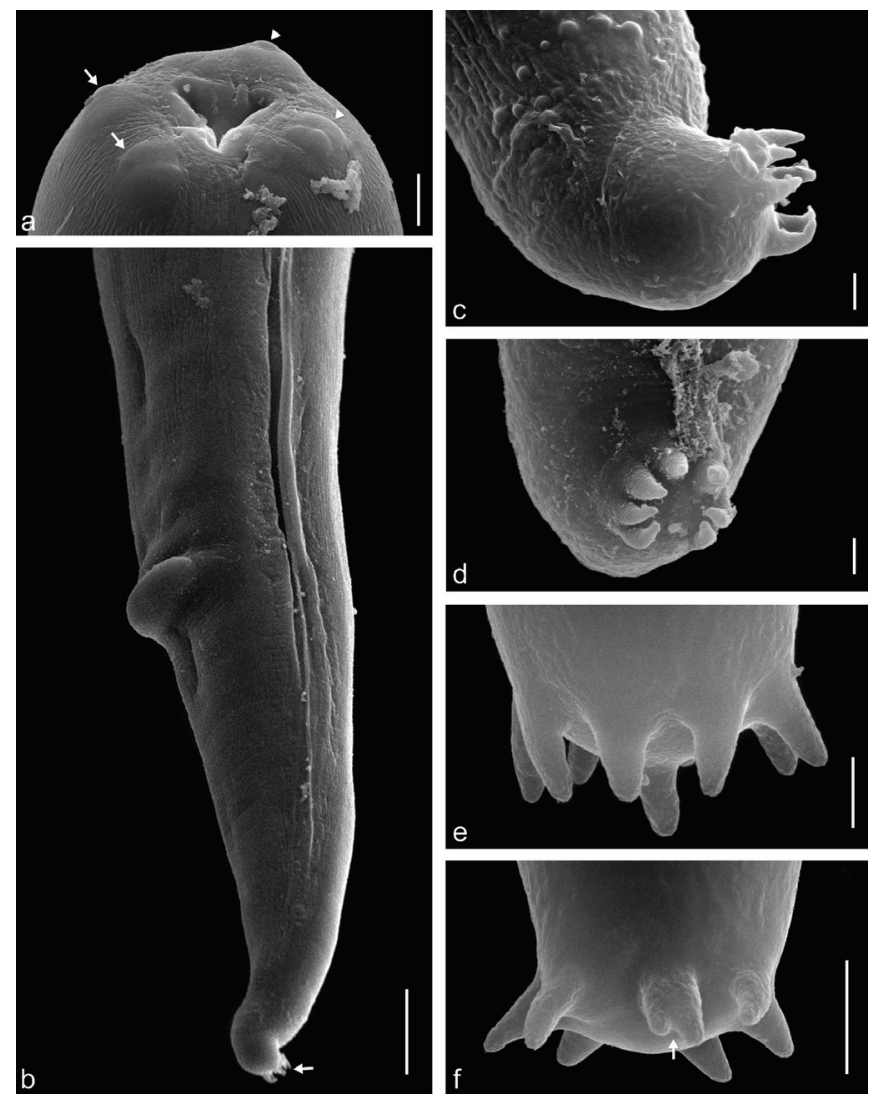

Figure 4. Scanning electron microscopy on Hysterothylacium fortalezae $\left(\mathrm{L}_{3}\right)$ in Selene setapinnis: a - anterior end showing the triangular opening mouth with one dorsal lip presenting two sets of papilla (arrow) and two lateroventral lips, each with a set of papillae (arrow head); $\mathbf{b}$ - posterior end showing the anus with projection and at the tip, in the dorsal direction, tuft of spinous structure (arrow); c - lateral view of tuft of spinous structure showing six spines; $\mathbf{d}$ - frontal view of tuft of spinous structure showing seven spines; $\mathbf{e}$ - tuft of spinous structure showing eight spines; $\mathbf{f}$ - tuft of spinous structure showing seven spines, one of them bifid, indicated by arrow. Scale bars in $\mathbf{a}$, $\mathbf{c}, \mathbf{d}$, e and $\mathbf{f}=5 \mu \mathrm{m}$, and $\mathbf{b}=20 \mu \mathrm{m}$.

Terranova specimens collected in the present study (VICENTE et al., 1985; VICENTE \& PINTO, 1999; TAVARES \& LUQUE, 2006).

The morphology and morphometry of the Terranova sp. thirdinstar larvae were similar to those reported by Timi et al. (2001) in Engraulis anchiota Hubbs \& Marini, 1935, from Argentina and Uruguay, and Felizardo et al. (2009a) in Paralichthys isosceles Jordan, 1890, from Brazil. Cordeiro \& Luque (2004) found Terranova sp. in the mesentery of $S$. setapinnis with a prevalence of $21.3 \%$. In this study, the prevalence was $13.3 \%$ but with more infection sites: both the mesentery and the liver serosa.

In this study, the $H$. fortalezae larvae collected were concordant with the morphological characteristics cited by Deardorff \& Overstreet (1981), which they reported in Scomberomorus maculatus (Mitchill, 1815), Peprilus alepidotus Linnaeus, 1766, P. burti Fowler, 1944 , and Anchoa hepsetus (Linnaeus, 1758), originating from the Gulf of Mexico. One of the main features of this species is the presence of a tuft of spinous structures in the tail; and $\mathrm{L}_{3}$ has approximately 
six of these structures (DEARDORFF \& OVERSTREET, 1981). In the present study, six to eight spinous structures were noted and were consistent with the previous description, but there was a difference in the larvae size with measurements from $1.7 \mathrm{~mm}$ to $3.5 \mathrm{~mm}$ for $\mathrm{L}_{3}$ and from $5.0 \mathrm{~mm}$ to $13.5 \mathrm{~mm}$ for $\mathrm{L}_{4}$. This shows that morphometric changes can occur in the parasite, in relation to its host and its habitat, as previously stated by Timi et al. (2001), and intraspecific variations can be caused by different fixing methods or by geographic variations and effects related the hosts as suggested by Hurst (1984), and must be related to the marine ecoregions of the world (SPALDING et al., 2007). In the present study, the observed total length of the larvae was $4.5 \mathrm{~mm}$ to $7.0 \mathrm{~mm}$. Some bifurcated spines were noted, suggesting that, in the ripening process and molting of the larvae, these structures grow in number from the preexisting spines and that the larvae may have been at an intermediate stage in the process of changing from $\mathrm{L}_{3}$ to $\mathrm{L}_{4}$ (Figure 4f).

The first records of the genus Hysterothylacium and the species $H$. fortalezae in Brazil were made by Klein (1973), along the coast of State of Ceará, in a study on adult parasites of the stomach and intestine of scombrid fish. Guimarães \& Cristofaro (1974) found this species in the intestine of Harengula clupeola (Cuvier, 1829) along the coast of the State of Bahia. In the present study, no adult specimens were found, thus indicating that the fish collected were serving as an intermediate host for this nematode.

Cavalcanti et al. (2012) reported the presence of 28 specimens of Contracaecum fortalezae ( $=H$. fortalezae) in the gill chambers and gonads of fifteen samples of Scomberomorus brasiliensis Collette, Russo \& Zavala-Camin, 1978, collected on the coast of the State of Rio Grande do Norte, Brazil. They also recorded a specimen of Hysterothylacium sp. parasitizing the intestine of Trichiurus lepturus Linnaeus, 1758. Cordeiro \& Luque (2004) found that the prevalence of Hysterothylacium sp. in S. setapinnis was $7.8 \%$ and that the mesentery was the infection site. This differed from the infection sites found in the present study, which consisted not only of the mesentery but also of the liver serosa and abdominal cavity. For comparison, the morphology and morphometry of the specimens deposited by Cordeiro \& Luque (2004) in CHIOC were analyzed. The samples that they classified as Hysterothylacium sp. were identified as $H$. fortalezae, because they showed morphology identical to the larvae collected now, with six to seven spines on the tail. The present study is the first report of this species parasitizing $S$. setapinnis.

Hysterothylacium fortalezae larvae have been reported on other hosts in the North Atlantic Ocean. Santana-Piñeros et al. (2012) found this type of larva in the intestine, mesentery, stomach and rectum of Symphurus plagiusa (Linnaeus, 1766) on the coast of Campeche, Mexico. Adult specimens of $H$. fortalezae were collected from the intestine of Oligoplites saurus (Bloch \& Schneider, 1801) and Scomberomorus maculatus (Mitchill, 1815) originating from the Bay of Chetumal, Mexico, by Aguirre-Macedo et al. (2007).

Hysterothylacium reliquens (Norris \& Overstreet, 1975) is another species of the genus Hysterothylacium that has been recorded in fish on the northeastern coast of Brazil. Its morphology is very close to that of $H$. fortalezae, but differs from the specimens found in the present study mainly in relation to the tail morphology, which has a multiple spiny structure with numerous tiny spines (DEARDORFF \& OVERSTREET, 1980, 1981).

The genus Hysterothylacium has been mentioned as important for health surveillance studies (CAVALCANTI et al., 2012; FELIZARDO et al., 2009a, 2009b; FONTENELLE et al., 2013; YAGI et al., 1996). Continuation of studies on this parasitism is of sanitary importance from a public health point of view, in order to implement and reinforce hygiene standards and fish quality control.

\section{Acknowledgements}

The authors would like to thank Marcia Christina Amorim Moreira Leite at the Electron Microscopy Laboratory, Institute of Chemistry, Universidade Estadual do Rio de Janeiro, for making the scanning electron microscope available; Heloisa Maria Nogueira Diniz and Rodrigo Mexas at the Image Production and Processing Service, Oswaldo Cruz Institute, for processing the figures; Coordination Office for Improvement of University-level Personnel; National Council for Scientific and Technological Development; and Carlos Chagas Research Support Foundation of the State of Rio do Janeiro.

\section{References}

Aguirre-Macedo ML, Vidal-Martínez VM, González-Solís D, Caballero PI. Helminth communities of four commercially important fish species from Chetumal Bay, Mexico. J Helminthol 2007; 81(1): 19-31. http:// dx.doi.org/10.1017/S0022149X0721209X. PMid:17381863

Amato JFR. Digenetic Trematodes of Percoid fishes of Florianópolis, southern Brazil. Fellodistomidae, Monascidae, Diplangidae, Zoogonidae, and Waretrematidae with description of two new species. Rev Bras Biol 1982; 42(4): 681-699.

Begossi A. O cerco flutuante e os caiçaras do litoral norte de São Paulo, com ênfase à pesca de Trindade, RJ. Interciencia 2011; 36(11): 803-807.

Bush AO, Lafferty KD, Lotz JM, Shostak AW. Parasitology meets ecology on its own terms: Margolis et al. revisited. J Parasitol 1997; 83(4): $575-$ 583. http://dx.doi.org/10.2307/3284227. PMid:9267395

Cavalcanti ETS, Takemoto RM, Alves LC, Chellappa S. First report of metazoan fish parasites with zoonotic potential in Scomberomorus brasiliensis and Trichiurus lepturus from the coastal waters of Rio Grande do Norte, Brazil. Mar Biodivers Rec 2012; 5(e40): 1-4. http://dx.doi. org/10.1017/S175526721200029.

Clauzet MA, Ramires MB, Barrella WC. Pesca artesanal e conhecimento local de duas populaçôes caiçaras (Enseada do Mar Virado e Barra do Una) no litoral de São Paulo, Brasil. Multiciencia 2005; 4: 1-22.

Cordeiro AS, Luque JL. Community ecology of the metazoan parasites of Atlantic moonfish, Selene setapinnis (Osteichthyes: Carangidae) from the coastal zone of the State of Rio de Janeiro, Brazil. Braz J Biol 2004; 64(3A): 399-406. http://dx.doi.org/10.1590/S1519-69842004000300004. PMid: 15622838

Deardorff TL, Overstreet RM. Larval Hysterothylacium (= Thynnascaris) (Nematoda: Anisakidae) from fishes and invertebrates in the Gulf of Mexico. Proc Helminthol Soc Wash 1981; 48(2): 113-126. 
DeardorffTL, Overstreet RM. Review of Hysterothylacium and Iheringascaris (both previously $=$ Thynnascaris) $($ Nematoda: Anisakidae) from the northern Gulf of Mexico. Proc Biol Soc Wash 1980; 93(4): 1035-1079.

Dyer WG, Williams EH Jr, Williams LB. Digenetic trematodes of marine fishes of the western and southwestern coasts of Puerto Rico. Proc Helminthol Soc Wash 1985; 52(1): 85-94.

Eiras JC, Takemoto RM, Pavanelli JC. Métodos de estudo e técnicas laboratoriais em parasitologia de peixes. 2nd ed. rev. ampl. Maringá: Editora da Universidade Estadual de Maringá; 2006.

Fagerholm HP. Systematic implications of male caudal morphology in ascaridoid nematode parasites. Syst Parasitol 1991; 19(3): 215-229. http:// dx.doi.org/10.1007/BF00011888.

Felizardo NN, Knoff M, Pinto RM, Gomes DC. Larval anisakid nematodes of the flounder Paralichthys isosceles Jordan, 1890 (Piscei: Teleostei) from Brazil. Neotrop Helminthol 2009a; 3(2): 57-64.

Felizardo NN, Menezes RC, Tortelly R, Knoff M, Pinto RM, Gomes DC. Larvae of Hysterothylacium sp. (Nematoda: Anisakidae) in the sole fish Paralichthys isosceles Jordan, 1890 (Pisces: Teleostei) from the littoral of the state of Rio de Janeiro, Brazil. Vet Parasitol 2009b; 166(1-2): 175177. http://dx.doi.org/10.1016/j.vetpar.2009.08.004. PMid:19713041

Fontenelle G, Knoff M, Felizardo NN, Lopes LMS, Clemente SC. Nematodes of zoonotic importance in Cynoscion guatucupa (Pisces) in the state of Rio de Janeiro. Rev Bras Parasitol Vet 2013; 22(2): 281-284. http://dx.doi.org/10.1590/S1984-29612013005000019. PMid:23778824

Guimarães JF, Cristofaro R. Contribuição ao estudo da fauna helmintológica de peixes do estado da Bahia. Atas Soc Biol Rio de 1974; 17(2): 81-85.

Hurst RJ. Identification and description of larval Anisakis simplex and Pseudoterranova decipiens (Anisakidae: Nematoda) from New Zealand water. NZ J Mar Freshw Res 1984; 18(2): 177-186. http://dx.doi.org/1 $0.1080 / 00288330.1984 .9516040$.

Klein VLM. Helmintos parasitos das espécies Scomberomus cavalla (Cuvier) e Scomberomus maculatus (Mitchill) do litoral Cearense. Contracaecum fortalezae sp. n. (Nematoda, Ascaroidea). Mem Inst Oswaldo Cruz 1973; 71(1-2): 199-202. http://dx.doi.org/10.1590/S0074-02761973000100013.

Knoff M, Felizardo NN, Iñiguez AM, Maldonado A Jr, Torres EJL, Pinto RM, et al. Genetic and morphological characterisation of a new species of the genus Hysterothylacium (Nematoda) from Paralichthys isosceles Jordan, 890 (Pisces: Teleostei) of the Neotropical Region, state of Rio de Janeiro, Brazil. Mem Inst Oswaldo Cruz 2012; 107(2): 186-193. http://dx.doi. org/10.1590/S0074-02762012000200006. PMid:22415256
Lopes Torres EJ, de Souza W, Miranda K. Comparative analysis of Trichuris muris surface using conventional, low vacuum, environmental and field emission scanning electron microscopy. Vet Parasitol 2013; 196(3-4): 409-416. http://dx.doi.org/10.1016/j.vetpar.2013.02.026. PMid:23537947.

Menezes NA, Figueiredo JL. Manual de peixes marinhos do Sudeste do Brasil. IV. Teleostei (3). São Paulo: Museu de Zoologia da Universidade de São Paulo; 1980.

Occhialini DS, Schwingel PR. Composição e variação espaço-temporal da captura da frota de traineiras entre 1997 e 1999 no Porto de Itajaí, SC. Notas Tec FACIMAR 2003; 7: 11-22.

Santana-Piñeros AM, Pech D, Vidal-Martínez VM. Spatial structure of the helminth parasite communities of the tonguefish, Symphurus plagiusa, from the Campeche coast, southern Mexico. Int J Parasitol 2012; 42(10): 911-920. http://dx.doi.org/10.1016/j.ijpara.2012.07.008. PMid:22921602

Spalding MD, Fox HE, Allen GR, Davidson N, Ferdaña ZA, Finlayson $\mathrm{M}$, et al. Marine Ecoregions of the World: A Bioregionalization of Coastal and Shelf Areas. Bioscience 2007; 57(7): 573-583. http://dx.doi. org/10.1641/B570707.

Tavares LER, Luque JLFA. Sistemática, biologia e importância em saúde coletiva das larvas de Anisakidae (Nematoda: Ascaridoidea) parasitas de peixes ósseos marinhos do Estado do Rio de Janeiro, Brasil. In: SilvaSouza AT. Sanidade de organismos aquáticos no Brasil. Maringá: Abrapoa; 2006. p. 297-328.

Timi JT, Sardella NH, Navone GT. Parasitic nematodes of Engraulis anchoita Hubbs et Marini, 1935 (Pisces, Engraulidae) of the Argentine and Uruguayan coasts, South West Atlantic. Acta Parasitol 2001; 46(3): 186-193.

Vicente JJ, Pinto RM. Nematóides do Brasil. Nematóides de peixes. Atualização: 1985-1998. Rev Bras Zool 1999; 16(3): 561-610. http:// dx.doi.org/10.1590/S0101-81751999000300001.

Vicente JJ, Rodrigues HO, Gomes DC. Nematóides do Brasil. 1 ${ }^{\text {a }}$ parte: nematóides de peixes. Atas Soc Biol Rio de 1985; 25: 1-79.

Wallet M, Kohn A. Trématodes parasites de poissons marins du littoral de Rio de Janeiro, Brésil. Mem Inst Oswaldo Cruz 1987; 82(1): 21-27. http://dx.doi.org/10.1590/S0074-02761987000100004.

Yagi K, Nagasawa K, Ishikura H, Nakagawa A, Sato N, Kikuchi K, et al. Female worm Hysterothylacium aduncum excreted from human: a case report. Kisechugaku Zasshi 1996; 45(1): 12-23. 